\title{
$\mathrm{CO}_{2}$ 와 $\mathrm{N}_{2}$ 혼합 비율에 따른 포장 닭고기 가슴육의 냉장 저장 중 품질 특성 \\ 채현석 · 나재천 · 최희철 · 김민지 · 방한태 · 강환구 · 김동욱 · 서옥석 · 함준상 · 장애라* 농촌진흥청 국립축산과학원
}

\section{Effect of Gas Mixture Ratio of Modified Atmosphere Packaging on Quality of Chicken Breast}

\author{
Hyun-Seok Chae, Jae-Cheon Na, Hee-Cheol Choi, Min-Ji Kim, Han-Tae Bang, Hwan-Ku Kang, \\ Dong-Wook Kim, Ok-Seok Suh, Jun-Sang Ham, and Aera Jang* \\ National Institute of Animal Science, RDA, Suwon 441-744, Korea
}

\begin{abstract}
The physicochemical characteristics of chicken breast were determined to identify the optimal ratio of $\mathrm{CO}_{2}$ and $\mathrm{N}_{2}$ to maintain chicken breast quality during cold storage for $6 \mathrm{~d}$. The mixing ratios of $\mathrm{CO}_{2}$ and $\mathrm{N}_{2}$ were 20:80, 40:60, 60:40, and $80: 20$, respectively. The $\mathrm{pH}$ of the chicken breast packed with $80 \% \mathrm{CO}_{2}$ and $20 \% \mathrm{~N}_{2}$ was lower than that of the control on day $1(p<0.05)$. The lightness $\left(\mathrm{L}^{*}\right)$ of the breast increased with increasing $\mathrm{CO}_{2}$ during storage $(p<0.05)$, whereas no difference was found for redness $\left(a^{*}\right)$ and yellowness $\left(b^{*}\right)$. A lower volatile basic nitrogen level was found for chicken breasts exposed to higher $\mathrm{CO}_{2}$ levels. Furthermore, lipid oxidation of the chicken breast packed with $\mathrm{CO}_{2}$ decreased with increasing $\mathrm{CO}_{2}$ level, and $40 \% \mathrm{CO}_{2}$ significantly reduced 2-thiobarbituric acid reactive substances (TBARS) values on days 1 and 6. The total number of microbes was reduced in chicken breast exposed to more than $40 \% \mathrm{CO}_{2}$ during storage days 3 and 6 $(p<0.05)$; however, Escherichia coli was not affected by $\mathrm{CO}_{2}$ level. Coliforms of chicken breast were reduced in the $40 \%$ $\mathrm{CO}_{2}$ level on storage day 3. Moreover, tray-packed chicken breast exposed to $40 \% \mathrm{CO}_{2}$ did not collapse. These results suggest that $40 \% \mathrm{CO}_{2}$ and $60 \% \mathrm{~N}_{2}$ were the optimal conditions for packaging chicken breasts during cold storage.
\end{abstract}

Key words: chicken breast, packaging, $\mathrm{CO}_{2}, \mathrm{~N}_{2}$, storage, quality

\section{서 론}

육계는 사육과정에서부터 좁은 공간에서 많은 무리를 모 아 사육 하면서 상호 교차 오염에 의해서 털, 분뇨 등에 많은 미생물이 존재한다. 농가에서 출하 후에 수송과정에 서도 좁은 차량 내에서 장시간 체류하는 동안 분뇨에 의 해 미생물 오염이 발생한다. 도축단계에서도 짧은 시간에 많은 수를 도축하면서 연속적으로 탕침, 세척, 냉각 과정 에서 일정한 수조를 통과하는 과정을 통해 미생물의 교차 오염이 쉽게 일어난다(Bailey et al., 1987). 또한 가금류는 도체 특성이 깃털을 뽑고 난 후에는 자국이 남아 미생물 이 부착하기 좋은 표피 구조를 가지고 있어서 도축과정에 서 여러 번의 세척과 소독제를 사용해도 쉽게 제거되지 않는다. 따라서 닭고기는 미생물이 존재한 상태에서 폴리

*Corresponding author: Aera Jang, National Institute of Animal Science, RDA, Suwon 441-744, Korea. Tel: 82-31-290-1685, Fax: 82-31-290-1697, Email: ajang@korea.kr
에틸렌(PE), 랩, 플라스틱 등으로 포장한 뒤 저온 보관이 제대로 이루어지지 않을 경우 오히려 미생물 번식이 더 빨라질 수도 있다. 본 연구에서 사용한 가스치환포장(MAP) 은 진공포장의 단점을 개선하기 위해 개발되었는데 식육 의 호흡속도를 늦추고 미생물의 성장을 감소시키며 효소 에 의한 분해를 저해시키는 역할을 한다(Banks et al., 1980; Bran et al., 1970). 가스 포장은 포장 내에 있는 공기를 제 거시키고 가스를 대신 채우는데 주로 사용하는 가스는 $\mathrm{CO}_{2}, \mathrm{~N}_{2}, \mathrm{O}_{2}$ 등이며 보통 이들의 공기를 혼합하여 사용한 다. 특히 $\mathrm{CO}_{2}$ 의 역할은 포장 내에서 식육 표면에 있는 수 분에 용해되어 식육의 $\mathrm{pH}$ 를 저하시켜 미생물의 성장을 억 제시키고 효소의 활력을 저하시킨다(Arashisar et al., 2004; Daniels et al., 1985; Finne, 1982; Gill and Mollin, 1991; Hotchkiss, 1989; Stammen et al., 1990). 그리고 식육의 세 포막의 수분을 제거함으로 세포 내로 유입하는 수용성 물 질의 통로를 막는 등 세포막의 투과성을 변화시킴으로 미 생물을 억제시킨다(Finne, 1982; Holland, 1980; Ogrydziak and Brown, 1982; Veranth and Robe, 1979; Wilhelm, 
1982). 그밖에 $\mathrm{O}_{2}$ 는 육색을 바람직하게 유지시켜주고 $\mathrm{N}_{2}$ 는 포장내의 충진제로 사용하며 찌그러짐을 방지하여 포 장의 형태를 유지하여 준다. Hood와 Mead(1993)는 안전 하게 축산물을 보호하고 본연의 육색을 나타내기 위해서 는 가스치환 포장이 좋은 방법이라고 소개하고 있다. 따 라서 본 연구는 닭고기의 가슴육을 분리하여 저장기간 동 안 품질을 유지할 수 있는 가스 비율을 제시하고자 수행 하였다.

\section{재료 및 방법}

\section{실험재료 및 가스혼합 처리}

본 연구에 사용한 250마리 육계는 농가에서 33일령 사 육한 Ross 품종으로 암, 수 구분 없이 각 처리구당 50마 리씩 평사에서 사육하였다. 실험당일 각 처리구당 5 마리 씩 선발하여 총 25 마리의 육계는 8 시간 정도 절식 시킨 후 일반 도계장에서 사용하는 방법에 따라 도계하였다. 내 장 및 다리, 목을 제거한 닭고기 도체는 실험 재료로 사 용하기 위하여 다리육, 날개육과 가슴살로 분리시켰다. 본 연구에서는 껍질을 제거한 닭고기 가슴살만을 이용하여 실험을 수행하였다. 가스치환포장기를 이용하여 $\mathrm{CO}_{2}$ 와 $\mathrm{N}_{2}$ 가스의 비율을 Table 1 과 같이 조정한 후 가슴살에 대하 여 가스치환포장 용기에 $500 \mathrm{~g}$ 단위로 포장을 하였다. 포 장을 마친 닭고기는 $4^{\circ} \mathrm{C}$ 냉장고에서 1-6일간 저장하면서 $1,3,6$ 일이 되었을 때 냉장고에서 꺼내어 분석용 시료로 공시하였다.

\section{$\mathrm{pH}$ 측정}

닭고기의 $\mathrm{pH}$ 는 닭고기의 가슴육을 분리하여 고기를 믹 서기로 잘게 부순 다음 $\mathrm{pH}$ 미터(Orion $410 \mathrm{~A}^{+}, \mathrm{USA}$ )를 이 용하여 측정하였다.

\section{색도}

육색은 표피를 제거한 가슴 근육 부위를 측정하였다. 측 정기기는 Chromameter (Minolta Co. CR 300, Japan)를 이 용하여 명도( $\mathrm{L}^{*}$ 값), 적색도 $\left(\mathrm{a}^{*}\right.$ 값), 황색도( $\mathrm{b}^{*}$ 값)에 대한 $\mathrm{CIE}$ (Commision Internationale de Leclairage) 값을 측정하 였다. 이때 사용한 표준판은 $\mathrm{Y}=92.40, \mathrm{x}=0.3136, \mathrm{y}=0.3196$

Table 1. Mixing ratio of gas in modified atmosphere packaging (MAP)

\begin{tabular}{cccccc}
\hline \hline \multirow{2}{*}{ Gases } & \multicolumn{5}{c}{ Treatments $^{1)}$} \\
\cline { 2 - 6 } & Control & $\mathrm{T} 1$ & $\mathrm{~T} 2$ & $\mathrm{~T} 3$ & $\mathrm{~T} 4$ \\
\hline $\mathrm{CO}_{2}$ & - & 20 & 40 & 60 & 80 \\
$\mathrm{~N}_{2}$ & - & 80 & 60 & 40 & 20
\end{tabular}

${ }^{1)}$ Control, without MAP packaging; T1, 20\% $\mathrm{CO}_{2}+80 \% \mathrm{~N}_{2}$; T2, $40 \% \mathrm{CO}_{2}+60 \% \mathrm{~N}_{2} ; \mathrm{T} 3,60 \% \mathrm{CO}_{2}+40 \% \mathrm{~N}_{2} ; \mathrm{T} 4,80 \% \mathrm{CO}_{2}+$ $20 \% \mathrm{~N}_{2}$
의 백색 타일을 사용하였다.

\section{단백질변패도}

단백질변패도를 나타내는 volatile basic nitrogen(VBN) 의 측정은 高坂(1975)의 방법을 이용하여 시료 $10 \mathrm{~g}$ 을 취 해서 증류수 $70 \mathrm{~mL}$ 와 함께 혼합하고 $100 \mathrm{~mL}$ volumetric flask로 옮겨 $100 \mathrm{~mL}$ 로 맞춘다. 다시 여과지를 사용하여 여과한 다음 여과액 $1 \mathrm{~mL}$ 을 conway unit 외실에 넣고 내 실에는 $0.01 \mathrm{~N}$ boric acid $1 \mathrm{~mL}$ 와 conway reagent $50 \mathrm{uL}$ ( $0.066 \%$ methyl red:bromocresol green/EtOH=1:1)를 3방울 떨어뜨렸다. 뚜껑과 접착부위에 글리세린을 바르고 뚜껑 을 닫은 후 $50 \%$ potassium carbonate $1 \mathrm{~mL}$ 을 외실에 주 입 후 즉시 밀폐한 다음 용기를 수평으로 교반시킨 후 $37^{\circ} \mathrm{C}$ 에서 120 분간 방치하고 $0.02 \mathrm{~N}$ 황산으로 적정하여 무 색이 되는 양을 측정하였다. $\mathrm{VBN}$ 은 아래의 식을 이용하 여 계산하였으며 $\mathrm{S}$ 는 시료 무게, $\mathrm{a}$ 는 시료를 적정한 황산 의 부피 $(\mathrm{mL}), \mathrm{b}$ 는 공시료를 적정한 황산의 부피 $(\mathrm{mL}), \mathrm{f}$ 는 $0.02 \mathrm{~N}$ 황산의 표준화 지수이다.

$\operatorname{VBN}(m g \%)=(a-b) \times f \times 0.02 \times 14.007 / S \times 100 \times 100$

\section{지방산패도}

지방산패도를 의미하는 2-Thiobarbituric acid reactive substances(TBARS)는 Witte 등(1970)의 방법에 의해 시료 $4 \mathrm{~g}$ 을 취하여 $2 \mathrm{M}$ 의 trichloro-acetic acid (in $2 \mathrm{M}$ phosphate) $50 \mathrm{~mL}$ 을 첨가하고 2 분간 $14,000 \mathrm{rpm}$ 에서 균질화하였다. 여 기에 증류수 $100 \mathrm{~mL}$ 을 첨가하여 교반하고, Whatman No. 1 여과지를 이용하여 여과한 후 여액 $5 \mathrm{~mL}$ thiobarbituric acid 용액 $(0.005 \mathrm{M}$ in distilled water) $5 \mathrm{~mL}$ 을 반응시켜 실 온 암소에서 15시간 방치한 후, $530 \mathrm{~nm}$ 에서 흡광도를 측 정하고 다음 식에 의하여 계산하였다.

TBARS ( $\mathrm{mg}$ of malondialdehyde/kg sample)

$=$ absorbance at $530 \mathrm{~nm} \times 5.2$

\section{미생물 변화}

미생물검사는 APHA(1985)의 swab method를 일부 수정 하여 이용하였다. 가슴부위의 표피 3 곳에 $10 \mathrm{~cm}^{2}$ 의 template 를 대고 멸균시킨 면봉(Techra Co., AU)으로 적신 후 멸 균 희석수에 넣어 적절한 비율로 희석하였다. 총균수는 희 석액을 aerobic count plate petrifilm $(3 \mathrm{M}$ Health care, $\mathrm{USA}$; $\mathrm{AOAC}, 1995$ )에 $1 \mathrm{~mL}$ 를 접종하여 $37^{\circ} \mathrm{C}$ 에서 2일간 배양한 후 군락 수를 계수 하였다. 대장균수도 총균수와 마찬가지로 E. coli/Coliform count plate petrifilm(3 M Health care, USA; AOAC, 1990)을 이용하여 희석액을 $1 \mathrm{~mL}$ 씩 접종한 후 $37^{\circ} \mathrm{C}$ 에서 24시간 배양한 후에 자란 군 락 수를 계수하였다. 


\section{통계분석}

SAS program (Statistics Analytical System, USA, 1999) 의 GLM (General Linear Model) 방법을 이용하여 분석하 였다. 처리군의 평균값 간의 비교를 위해 Duncan의 다중 검정(Multiple Range Test)을 이용하여 5\% 수준에서 유의 성 검정을 실시하였다.

\section{결과 및 고찰}

\section{$\mathrm{pH}$ 변화}

가스비율에 따른 저장기간별 가슴육의 $\mathrm{pH}$ 변화는 Table 2 와 같다. 저장 1 일에 닭고기 가슴육 포장 용기 내 $\mathrm{CO}_{2}$ 가 $20 \%$ 함유된 경우보다 $60 \%$ 와 $80 \%$ 를 차지하였을 때 닭고 기 가슴육의 $\mathrm{pH}$ 가 유의적으로 감소하였으며 대조군과 비 교한 경우 $80 \% \mathrm{CO}_{2}$ 함유시에 유의적으로 낮은 수준을 나 타내었다 $(p<0.05)$. 일반적으로 닭고기 가슴육의 $\mathrm{pH}$ 범위 는 5.5-6.0인데(Gill et al., 1990), Choulia 등(2007)은 대조 구와 $\mathrm{CO}_{2}$ 의 농도를 $30-70 \%$ 로 변경할 때 6.4 5.9까지 감 소하였다고 하여 $80 \% \mathrm{CO}_{2}$ 에서 5.74 로 유의적인 감소를 보였던 저장 1 일차의 본 연구와 유사한 경향을 나타내었 다. Jakobsen과 Bertelsen(2002)은 식육 조직내 다량의 $\mathrm{CO}_{2}$ 가 흡수되면 $\mathrm{pH}$ 가 다소 감소하게 되는데 이는 발생된 탄 산가스가 중탄산염과 수소이온으로 해리되기 때문이라고
하였다. 저장 3 일에는 닭고기 가슴육의 $\mathrm{pH}$ 가 대조구의 경 우 5.89를 나타낸 반면에 $\mathrm{CO}_{2}$ 농도가 $20,40,80 \%$ 일 때 각각 $5.68,5.96,6.01$ 으로 나타났다. 그러나 $\mathrm{CO}_{2}$ 농도가 증가함에 따른 유의적인 $\mathrm{pH}$ 의 감소는 보이지 않았다. 저 장 6일의 경우에도 $\mathrm{CO}_{2}$ 농도가 증가함에 따라 닭 가슴육 의 $\mathrm{pH}$ 가 감소하는 경향을 보였으나 유의적인 차이는 보 이지 않았다. Vihavainen 등(2007)은 $80 \% \mathrm{CO}_{2}+20 \% \mathrm{~N}_{2}$ 이었을 때 저장기간에 따라 육계의 $\mathrm{pH}$ 는 5.8-6.1까지 변 화를 나타낸다고 보고하였다. 그러나 Zaika 등(1983)과 Patsias 등(2008)은 MAP에서는 가스 농도에 따른 $\mathrm{pH}$ 변 화는 유의적인 차이가 없다고 보고하였다.

\section{육색변화}

가스비율에 따른 저장기간별 가슴육의 명도 $\left(\mathrm{L}^{*}\right)$ 변화는 Table 3 과 같다. 저장 1 일에 $\mathrm{CO}_{2}$ 의 비율이 $20,40,60$, $80 \%$ 로 증가할수록 $52.30,53.70,55.42,57.92$ 로 대조구와 $20 \%$ 와 $40 \%$ 사이에는 유의적인 차이를 보이지 않았으나 $60 \%$ 와 $80 \%$ 의 농도에서는 유의적인 증가를 나타내었다 $(p<0.05)$. 이러한 경향은 저장 3일과 6일에도 보여 $80 \%$ $\mathrm{CO}_{2}+20 \% \mathrm{~N}_{2}$ 에서 가장 높은 명도 값을 나타내었다 $(p<0.05)$. 저장기간에 따라서는 $40 \% \mathrm{CO}_{2}+60 \% \mathrm{~N}_{2}$ 의 경우는 저장 1 일에 53.70, 저장 3일에 55.33, 저장 6일에 57.74로 저장 기간이 증가할수록 명도 값이 증가하는 경향을 나타내었

Table 2. Change of pH of chicken breast packaged with different ratio of $\mathrm{CO}_{2}$ and $\mathrm{N}_{2}$ during cold storage

\begin{tabular}{cccccc}
\hline \hline \multirow{2}{*}{ Days } & \multicolumn{5}{c}{ Treatments ${ }^{1)}$} \\
\cline { 2 - 6 } & Control & $\mathrm{T} 1$ & $\mathrm{~T} 2$ & $\mathrm{~T} 3$ & $\mathrm{~T} 4$ \\
\hline 1 & $5.93^{\mathrm{c}} \pm 0.04$ & $6.35^{\mathrm{aA}} \pm 0.11$ & $6.28^{\mathrm{abA}} \pm 0.06$ & $6.18^{\mathrm{bA}} \pm 0.05$ & $5.74^{\mathrm{dB}} \pm 0.03$ \\
3 & $5.89^{\mathrm{b}} \pm 0.06$ & $5.68^{\mathrm{cC}} \pm 0.05$ & $5.96^{\mathrm{abB}} \pm 0.01$ & $6.09^{\mathrm{aAB}} \pm 0.10$ & $6.01^{\mathrm{abA}} \pm 0.10$ \\
6 & $5.92^{\mathrm{ab}_{2}} \pm 0.09$ & $6.10^{\mathrm{aB}} \pm 0.03$ & $5.96^{\mathrm{abB}} \pm 0.07$ & $5.90^{\mathrm{abB}} \pm 0.19$ & $5.77^{\mathrm{bB}} \pm 0.06$ \\
\hline
\end{tabular}

${ }^{\mathrm{a}-\mathrm{d}}$ Means with different superscripts within a row significantly differ at $p<0.05$.

${ }^{\text {A-C }}$ Means with different superscripts within a column significantly differ at $p<0.05$.

${ }^{1)}$ Control, without MAP packaging; T1, 20\% $\mathrm{CO}_{2}+80 \% \mathrm{~N}_{2}$; T2, 40\% $\mathrm{CO}_{2}+60 \% \mathrm{~N}_{2} ; \mathrm{T} 3,60 \% \mathrm{CO}_{2}+40 \% \mathrm{~N}_{2} ; \mathrm{T} 4,80 \% \mathrm{CO}_{2}+20 \% \mathrm{~N}_{2}$

Table 3. Change of color of chicken breast without skin by packaging with different ratio of $\mathrm{CO}_{2}$ and $\mathrm{N}_{2}$ during cold storage

\begin{tabular}{|c|c|c|c|c|c|c|}
\hline \multirow{2}{*}{ Color } & \multirow{2}{*}{ Days } & \multicolumn{5}{|c|}{ (Treatments ${ }^{1)}$} \\
\hline & & Control & $\mathrm{T} 1$ & $\mathrm{~T} 2$ & $\mathrm{~T} 3$ & $\mathrm{~T} 4$ \\
\hline \multirow{3}{*}{$\begin{array}{c}\text { CIE } \\
\mathrm{L}^{*}\end{array}$} & 1 & $52.53^{\mathrm{c}} \pm 1.66$ & $52.30^{\mathrm{cC}} \pm 0.72$ & $53.70^{\mathrm{bcB}} \pm 0.78$ & $55.42^{\mathrm{bB}} \pm 1.46$ & $57.92^{\mathrm{a}} \pm 1.31$ \\
\hline & 3 & $53.45^{\mathrm{c}} \pm 1.96$ & $53.74^{\mathrm{cB}} \pm 0.52$ & $55.33^{\mathrm{bcB}} \pm 1.35$ & $57.99^{\mathrm{abAB}} \pm 1.79$ & $59.34^{\mathrm{a}} \pm 1.79$ \\
\hline & 6 & $55.36^{\mathrm{c}} \pm 1.17$ & $55.32^{\mathrm{cA}} \pm 0.74$ & $57.74^{\mathrm{bcA}} \pm 0.54$ & $59.09^{\mathrm{bA}} \pm 0.64$ & $61.61^{\mathrm{a}} \pm 2.63$ \\
\hline \multirow{3}{*}{$\begin{array}{c}\text { CIE } \\
a^{*}\end{array}$} & 1 & $1.39 \pm 0.84$ & $1.13^{\mathrm{B}} \pm 0.34$ & $1.09^{\mathrm{B}} \pm 0.09$ & \pm 0.98 & $1.07 \pm 0.37$ \\
\hline & 3 & $1.55 \pm 0.64$ & $1.69^{\mathrm{A}} \pm 0.24$ & $0.86^{\mathrm{C}} \pm 0.04$ & \pm 0.88 & $0.90 \pm 0.77$ \\
\hline & 6 & $0.92 \pm 0.64$ & $1.11^{\mathrm{B}} \pm 0.21$ & $1.31^{\mathrm{A}} \pm 0.04$ & \pm 0.08 & $1.23 \pm 1.68$ \\
\hline \multirow{3}{*}{$\begin{array}{c}\text { CIE } \\
\text { b* }\end{array}$} & 1 & $2.16 \pm 0.82$ & $2.35^{\mathrm{B}} \pm 0.89$ & \pm 0.09 & \pm 1.55 & $5.23 \pm 0.55$ \\
\hline & 3 & $5.93 \pm 0.10$ & $5.08^{\mathrm{A}} \pm 0.97$ & \pm 1.42 & \pm 1.76 & $6.97 \pm 4.45$ \\
\hline & 6 & $3.25 \pm 0.23$ & $3.69^{\mathrm{AB}} \pm 1.55$ & \pm 1.51 & \pm 1.77 & $6.17 \pm 1.70$ \\
\hline
\end{tabular}

\footnotetext{
${ }^{\mathrm{a}-\mathrm{c}}$ Means with different superscripts within a row significantly differ at $p<0.05$.

${ }^{A-C}$ Means with different superscripts within a column significantly differ at $p<0.05$.

${ }^{1)}$ Control, without MAP packaging; T1, 20\% $\mathrm{CO}_{2}+80 \% \mathrm{~N}_{2}$; T2, $40 \% \mathrm{CO}_{2}+60 \% \mathrm{~N}_{2} ; \mathrm{T} 3,60 \% \mathrm{CO}_{2}+40 \% \mathrm{~N}_{2} ; \mathrm{T} 4,80 \% \mathrm{CO}_{2}+20 \% \mathrm{~N}_{2}$
} 
다. 이러한 경향은 $\mathrm{CO}_{2}$ 의 비율이 $20,60 \%$ 에서도 비슷하 게 나타났다. Patsias 등(2008)은 $30 \% \mathrm{CO}_{2}+70 \% \mathrm{~N}_{2}$ 로 닭 고기를 포장하였을 때 저장 15 일에 명도 값 $\left(\mathrm{L}^{*}\right)$ 이 57.8 을 보였다고 보고하였다. 가스비율에 따른 저장기간별 가슴 육의 적색도 변화를 살펴보면 저장 1 일의 경우 $\mathrm{CO}_{2}$ 의 비 율이 $20,40,60,80 \%$ 로 증가할수록 $1.13,1.09,1.36,1.07$ 을 보여 $\mathrm{CO}_{2}$ 처리농도에 따른 일정한 경향은 보이지 않았 다. 이러한 경향은 저장 3 일과 6 일에도 보여 $\mathrm{CO}_{2}$ 와 $\mathrm{N}_{2}$ 처 리농도에 따른 변화는 없었다. Patsias 등(2008)은 $30 \% \mathrm{CO}_{2}$ 와 $70 \% \mathrm{~N}_{2}$ 로 포장하였을 때 저장 15 일에 적색도 값 $\left(\mathrm{a}^{*}\right)$ 이 대조구의 3.9에 비해 가스치환포장에서 3.4을 보였으나 유의적인 차이는 없었다고 하여 $\mathrm{CO}_{2}$ 처리에 따른 변화는 없었던 본 연구결과와 유사한 결과를 나타내었다. 또한 닭 가슴육의 황색도도 $\mathrm{CO}_{2}$ 처리농도에 따른 변화는 보이지 않았다. Patsias 등(2008)도 $30 \% \mathrm{CO}_{2}$ 로 포장하였을 때 황 색도가 $\left(\mathrm{b}^{*}\right)$ 대조구의 12.6 에 비해 저장 15 일에 가스치환포 장에서 12.1 을 보였으나 유의적인 차이는 없었다고 하였다.

\section{단백질변패도 측정}

가스비율에 따른 저장기간별 가슴육의 $\mathrm{VBN}$ 값의 변화 는 Table 4 와 같다. 저장 1 일에는 $\mathrm{CO}_{2}$ 의 비율이 $40 \sim 80 \%$ 로 증가하면서 대조군에 비해 $\mathrm{VBN}$ 의 유의적인 감소를 나 타내었다 $(p<0.05)$. 또한 저장 3 일에 $\mathrm{CO}_{2}$ 의 비율이 20,40 , $60,80 \%$ 으로 증가함에 따라 $6.49,6.31,5.76,5.40 \mathrm{mg} \%$ 을 보여 $\mathrm{CO}_{2}$ 농도가 60 과 $80 \%$ 일 때 $\mathrm{VBN}$ 값이 유의적으로 감소하였다 $(p<0.05)$. 저장 6 일에서도 대조구가 $8.37 \mathrm{mg} \%$
을 나타낸 반면에 $20 \% \mathrm{CO}_{2}$ 에서 $8.28 \mathrm{mg} \%, 40 \% \mathrm{CO}_{2}$ 에 서 $7.91 \mathrm{mg} \%, 60 \% \mathrm{CO}_{2}$ 에서 $7.09 \mathrm{mg} \%, 80 \% \mathrm{CO}_{2}$ 에서 $6.72 \mathrm{mg} \%$ 로 저장 3 일과 비슷한 경향을 나타내었으며 $40 \%$ $\mathrm{CO}_{2}$ 이상에서 $\mathrm{VBN}$ 값도 감소하였는데 $60 \% \mathrm{CO}_{2}$ 와 $80 \%$ $\mathrm{CO}_{2}$ 처리구간의 유의적인 차이는 보이지 않았다. 이는 휘 발성 염기태 질소가 미생물의 증식 정도와 밀접한 관계가 있어서 $\mathrm{CO}_{2}$ 와 $\mathrm{N}_{2}$ 가스를 처리함에 따라 미생물의 수가 억제되면서 단백질변성이 억제되어 저장성이 증가한 것으 로 사료된다(Kang et al., 2002; Kim, 2009).

\section{지방산패도 측정}

가스비율에 따른 저장기간별 가슴육의 지방산패도 (TBARS) 값의 변화는 Table 5 와 같다. 저장 1 일에는 모 든 $\mathrm{CO}_{2}$ 처리구에서 효과적으로 유의적인 감소를 나타내 었으며 $(\mathrm{p}<0.05)$, 저장 3 일에는 대조구가 $0.17 \mathrm{mg} \mathrm{MDA} / \mathrm{kg}$ 을 나타낸 반면에 $\mathrm{CO}_{2}$ 의 비율이 $60 \%$ 이상이 되면 대조 구보다 낮은 TBARS값을 나타내었다. 저장 6 일째에는 대 조구가 $2.20 \mathrm{mg} \mathrm{MDA} / \mathrm{kg}$ 를 나타낸 반면에 $\mathrm{CO}_{2}$ 가 $40 \%$ 이 상이 되면 대조구에 비해 유의적으로 낮은 TBARS값을 나타냄을 보여주었다. 이러한 결과는 닭고기에 $\mathrm{CO}_{2}$ 와 $\mathrm{N}_{2}$ 가스를 처리함에 따라 지방산패가 억제되어 저장성이 증 가하였음을 보여준 것으로 판단된다. $\mathrm{Kim}$ 등(1995)은 칠 면조 고기에서 저장 7일 경과 후 TBARS 값이 0.13-0.68 $\mathrm{mg} \mathrm{MDA} / \mathrm{kg}$ 를 나타내었으며, Chouliara 등(2007)은 저장 6 일에 $30 \% \mathrm{CO}_{2}+70 \% \mathrm{~N}_{2}$ 의 경우 $0.90 \mathrm{mg} \mathrm{MDA} / \mathrm{kg}, 70 \%$ $\mathrm{CO}_{2}+30 \% \mathrm{~N}_{2}$ 의 경우 $0.50 \mathrm{mg} \mathrm{MDA} / \mathrm{kg}$ 로 $\mathrm{CO}_{2}$ 의 농도가

Table 4. Change of volatile basic nitrogen (VBN) of chicken breast packaged with different ratio of $\mathrm{CO}_{2}$ and $\mathrm{N}_{2}$ during cold storage

\begin{tabular}{cccccc}
\hline \hline \multirow{2}{*}{ Days } & \multicolumn{5}{c}{ Treatments ${ }^{1)}$} \\
\cline { 2 - 6 } & Control & $\mathrm{T} 1$ & $\mathrm{~T} 2$ & $\mathrm{~T} 3$ & $\mathrm{~T} 4$ \\
\hline 1 & $4.98^{\mathrm{aC}} \pm 0.16$ & $4.76^{\mathrm{abC}} \pm 0.16$ & $4.48^{\mathrm{bC}} \pm 0.16$ & $3.61^{\mathrm{cC}} \pm 0.42$ & $3.52^{\mathrm{cC}} \pm 0.60$ \\
3 & $6.59^{\mathrm{aB}} \pm 0.27$ & $6.49^{\mathrm{aB}} \pm 0.16$ & $6.31^{\mathrm{aB}} \pm 0.27$ & $5.76^{\mathrm{bB}} \pm 0.27$ & $5.40^{\mathrm{bB}} \pm 0.16$ \\
6 & $8.37^{\mathrm{aA}} \pm 0.27$ & $8.28^{\mathrm{abA}} \pm 0.16$ & $7.91^{\mathrm{bA}} \pm 0.16$ & $7.09^{\mathrm{cA}} \pm 0.16$ & $6.72^{\mathrm{cA}^{\mathrm{AA}}} \pm 0.27$ \\
\hline
\end{tabular}

${ }^{\mathrm{a}-\mathrm{c}}$ Means with different superscripts within a row significantly differ at $p<0.05$.

${ }^{A-C}$ Means with different superscripts within a column significantly differ at $p<0.05$.

${ }^{1)}$ Control, without MAP packaging; T1, 20\% $\mathrm{CO}_{2}+80 \% \mathrm{~N}_{2} ; \mathrm{T} 2,40 \% \mathrm{CO}_{2}+60 \% \mathrm{~N}_{2} ; \mathrm{T} 3,60 \% \mathrm{CO}_{2}+40 \% \mathrm{~N}_{2} ; \mathrm{T} 4,80 \% \mathrm{CO}_{2}+20 \% \mathrm{~N}_{2}$

Table 5. Change of 2-thiobarbituric acid reactive substance (TBARS) of chicken breast packaged with different ratio of $\mathrm{CO}_{2}$ and $\mathrm{N}_{2}$ during cold storage

\begin{tabular}{cccccc}
\hline \hline \multirow{2}{*}{ Days } & \multicolumn{5}{c}{ Treatments $^{1)}$} \\
\cline { 2 - 6 } & Control & $\mathrm{T} 1$ & $\mathrm{~T} 2$ & $\mathrm{~T} 3$ & $\mathrm{~T} 4$ \\
\hline 1 & $0.16^{\mathrm{aB}} \pm 0.02$ & $0.12^{\mathrm{bC}} \pm 0.01$ & $0.12^{\mathrm{bC}} \pm 0.01$ & $0.11^{\mathrm{bcC}} \pm 0.02$ & $0.10^{\mathrm{cC}} \pm 0.01$ \\
3 & $0.17^{\mathrm{aB}} \pm 0.01$ & $0.16^{\mathrm{aB}} \pm 0.02$ & $0.16^{\mathrm{aB}} \pm 0.01$ & $0.14^{\mathrm{bB}} \pm 0.01$ & $0.14^{\mathrm{bB}} \pm 0.00$ \\
6 & $0.20^{\mathrm{aA}} \pm 0.01$ & $0.19^{\mathrm{aA}} \pm 0.01$ & $0.17^{\mathrm{bA}} \pm 0.01$ & $0.17^{\mathrm{bA}} \pm 0.00$ & $0.17^{\mathrm{bA}} \pm 0.01$ \\
\hline
\end{tabular}

\footnotetext{
${ }^{\mathrm{a}-\mathrm{c}}$ Means with different superscripts within a row significantly differ at $p<0.05$.

${ }^{\text {A-C }}$ Means with different superscripts within a column significantly differ at $p<0.05$.

${ }^{1)}$ Control, without MAP packaging; T1, 20\% $\mathrm{CO}_{2}+80 \% \mathrm{~N}_{2} ; \mathrm{T} 2,40 \% \mathrm{CO}_{2}+60 \% \mathrm{~N}_{2} ; \mathrm{T} 3,60 \% \mathrm{CO}_{2}+40 \% \mathrm{~N}_{2} ; \mathrm{T} 4,80 \% \mathrm{CO}_{2}+20 \% \mathrm{~N}_{2}$
} 
증가할수록 $\mathrm{TBA}$ 값의 감소를 보였다고 하여 본 연구와 유사한 경향을 나타내었다. 이는 $\mathrm{CO}_{2}$ 처리가 미생물 대사 에 의해 산화가 일어나면서 발생되는 carbonyl complex, alcohol, ketone, aldehyde 등의 부산물에 의한 TBAmalonaldehyde 복합체 형성을 억제시키기 때문인 것으로 판단된다(Kang et al., 2002).

\section{미생물 변화}

가스비율에 따른 저장기간별 가슴육의 총균수, 대장균 및 대장균군의 변화는 Table 6 과 같다. 총균수의 경우 저 장 1 일에는 $\mathrm{CO}_{2}$ 를 처리하지 않는 대조구에서 $3.59 \mathrm{Log}$ $\mathrm{CFU} / \mathrm{g}$ 을 보였으나 $\mathrm{CO}_{2}$ 를 처리한 구에서는 3.07-3.40의 수 준을 보여 유의적인 차이를 보이지 않았다. 저장 3 일에는 대조구가 4.77을 나타낸 반면에 $\mathrm{CO}_{2}$ 의 비율이 $20,40,60$, $80 \%$ 증가함에 따라 $4.64,4.06,3.49,3.24 \mathrm{Log} \mathrm{CFU} / \mathrm{g}$ 으 로 $\mathrm{CO}_{2}$ 의 비율이 $40 \%$ 이상의 수준이 될수록 총균수도 유 의적인 감소를 나타내었다 $(p<0.05)$. 저장 6 일에서도 대조 구가 $6.39 \mathrm{Log} \mathrm{CFU} / \mathrm{g}$ 을 나타낸 반면에 $\mathrm{CO}_{2}$ 농도가 20 , $40,60,80 \%$ 수준에서 각각 $6.01,5.38,4.90,4.82 \mathrm{Log}$ $\mathrm{CFU} / \mathrm{g}$ 로 저장 3 일과 비슷한 경향을 나타내며 $\mathrm{CO}_{2}$ 비율이 $40 \%$ 이상이 되면서 총균수도 감소함을 나타내었다 $(p<0.05)$. Church(1994)는 가스치환포장은 미생물의 성장에 영향을 미치며 특히 $\mathrm{N}_{2}$ 는 고기내의 미생물의 대사 반응을 최소화 하는 역할을 한다고 보고하였다. Jakobson과 Bertelsen (2002)은 $\mathrm{CO}_{2}$ 가 포화가 될 때까지 고기내의 물과 지방에 의해 흡수되어 미생물을 억제한다고 하였다. 즉, $\mathrm{CO}_{2}$ 가 고 기표면 부패균의 성장을 억제하는 기작에는 여러 가지가 있는데 포장 용기내 $\mathrm{CO}_{2}$ 는 식육의 표면에 존재하는 수분 에 용해되어 식육의 $\mathrm{pH}$ 를 저하시켜 미생물의 활성을 억 제하고 효소의 활성도 억제시키게 된다(Kim, 2009). 또한 세포막을 구성하고 있는 수분을 제거시켜 세포 내 유입

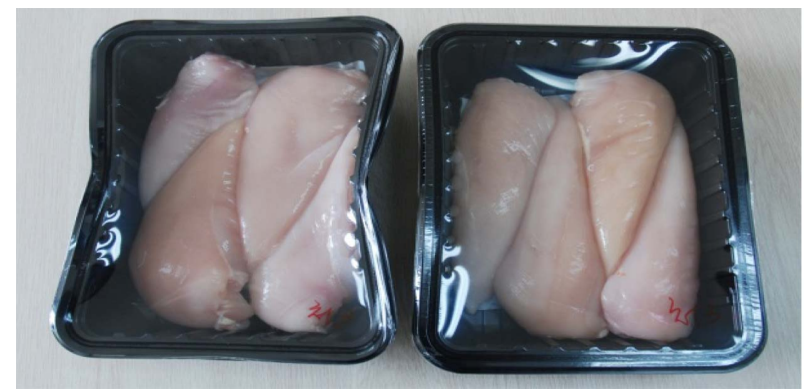

Fig. 1. Tray collapse of packed chicken with modified atmosphere with $\mathrm{CO}_{2}$ and $\mathbf{N}_{2}$. Left: Packed chicken with an atmosphere containing $60 \% \mathrm{CO}_{2}$ and $40 \% \mathrm{~N}_{2}$, Right: Packed chicken with an atmosphere containing $40 \% \mathrm{CO}_{2}$ and $60 \% \mathrm{~N}_{2}$.

수용성물질의 경로 차단을 통한 세포막 투과성을 변화시 켜 미생물의 신진대사를 억제하게 된다. Farber(1991)는 $\mathrm{CO}_{2}$ 농도가 높은 가스치환포장에서는 주로 호기성 균의 억제를 가져왔으며, Chouliara 등(2007)은 저장 6일에 대 조구가 $7.19,30 \% \mathrm{CO}_{2}+70 \% \mathrm{~N}_{2}$ 의 경우 $5.98,70 \% \mathrm{CO}_{2}+$ $30 \% \mathrm{~N}_{2}$ 의 경우 $4.86 \mathrm{Log} \mathrm{CFU} / \mathrm{g}$ 로 $\mathrm{CO}_{2}$ 의 농도가 증가할 수록 총균수의 감소를 가져와 본 연구와 비슷한 경향을 나타내었다. Sawaya 등(1995)은 $\mathrm{CO}_{2}$ 의 농도가 $30-70 \%$ 의 포장의 경우 신선 닭고기에서 미생물 억제를 통해 유리지 방산의 생산을 억제한다고 보고하였다. 닭고기 가공육에 서도 가스혼합포장을 한 경우 저장 14 일에 총균수가 1.5 $\log \mathrm{CFU} / \mathrm{g}$ 가 감소하였다고 보고하고 있다(Dawson et al., 1995). 저장기간별 가슴육의 E. Coli 수의 변화는 $\mathrm{CO}_{2}$ 와 $\mathrm{N}_{2}$ 가스 처리에 의한 유의적인 차이를 볼 수가 없었으며, 대조구 및 $\mathrm{CO}_{2}$ 처리구에서 E. Coli의 수는 0.20-0.26 Log $\mathrm{CFU} / \mathrm{cm}^{2}$ 의 범위를 나타내었다. 또한 Coliform 수의 변화 를 살펴보면 저장 1 일에는 대조구에서 $0.69 \mathrm{Log} \mathrm{CFU} / \mathrm{cm}^{2}$

Table 6. Change of microbes of chicken breast packaged with different ratio of $\mathrm{CO}_{2}$ and $\mathrm{N}_{2}$ during cold storage

(Unit: $\log \mathrm{CFU} / \mathrm{cm}^{2}$ )

\begin{tabular}{|c|c|c|c|c|c|c|}
\hline \multirow{2}{*}{ Microbes } & \multirow{2}{*}{ Days } & \multicolumn{5}{|c|}{ Treatments $^{1)}$} \\
\hline & & Control & $\mathrm{T} 1$ & $\mathrm{~T} 2$ & $\mathrm{~T} 3$ & $\mathrm{~T} 4$ \\
\hline \multirow{3}{*}{$\begin{array}{l}\text { Total } \\
\text { microbes }\end{array}$} & 1 & $3.59^{\mathrm{C}} \pm 0.51$ & $3.13^{\mathrm{C}} \pm 0.06$ & $3.20^{\mathrm{C}} \pm 0.08$ & $3.40^{\mathrm{B}} \quad \pm 0.13$ & $3.07^{\mathrm{B}} \pm 0.18$ \\
\hline & 3 & $4.77^{\mathrm{aB}} \pm 0.05$ & $4.64^{\mathrm{aB}} \pm 0.15$ & $4.06^{\mathrm{bB}} \pm 0.06$ & $3.49^{\mathrm{cB}} \pm 0.08$ & $3.24^{\mathrm{dB}} \pm 0.11$ \\
\hline & 6 & $6.39^{\mathrm{aA}} \pm 0.16$ & $6.01^{\mathrm{aA}} \pm 0.03$ & $5.38^{\mathrm{bA}} \pm 0.07$ & $4.90^{\mathrm{cA}} \pm 0.09$ & $4.82^{\mathrm{cA}} \pm 0.24$ \\
\hline \multirow{3}{*}{ E. coli } & 1 & $0.26^{\mathrm{C}} \pm 0.24$ & $0.20 \quad \pm 0.17$ & $0.26^{\mathrm{B}} \pm 0.24$ & \pm 0.24 & \pm 0.17 \\
\hline & 3 & $0.77^{\mathrm{B}} \pm 0.68$ & $0.67 \pm 0.58$ & $0.42^{\mathrm{B}} \quad \pm 0.10$ & \pm 0.10 & \pm 0.24 \\
\hline & 6 & $2.00^{\mathrm{A}} \pm 0.00$ & $1.77 \pm 1.53$ & $1.26^{\mathrm{A}} \quad \pm 0.24$ & \pm 0.24 & $0.46 \pm 0.15$ \\
\hline \multirow{3}{*}{ Coliforms } & 1 & $0.69^{\mathrm{aC}} \pm 0.09$ & $0.66^{\mathrm{a}} \pm 0.10$ & $0.36^{\mathrm{abB}} \pm 0.32$ & $0.26^{\mathrm{bB}} \pm 0.24$ & $0.20^{\mathrm{b}} \pm 0.17$ \\
\hline & 3 & $1.26^{\mathrm{aB}} \pm 0.24$ & $1.20^{\mathrm{a}} \pm 0.17$ & $0.68^{\mathrm{bB}} \pm 0.17$ & $0.36^{\mathrm{bAB}} \pm 0.10$ & $0.36^{\mathrm{b}} \pm 0.32$ \\
\hline & 6 & $2.36^{\mathrm{A}} \pm 0.10$ & $1.92 \pm 0.66$ & $1.76^{\mathrm{A}} \pm 0.15$ & $0.78^{\mathrm{A}} \quad \pm 0.26$ & $0.65 \pm 0.16$ \\
\hline
\end{tabular}

${ }^{\mathrm{a}-\mathrm{d}}$ Means with different superscripts within a row significantly differ at $p<0.05$.

${ }^{\mathrm{A}-\mathrm{C}}$ Means with different superscripts within a column significantly differ at $p<0.05$.

${ }^{1)}$ Control, without MAP packaging; T1, 20\% $\mathrm{CO}_{2}+80 \% \mathrm{~N}_{2} ; \mathrm{T} 2,40 \% \mathrm{CO}_{2}+60 \% \mathrm{~N}_{2} ; \mathrm{T} 3,60 \% \mathrm{CO}_{2}+40 \% \mathrm{~N}_{2} ; \mathrm{T} 4: 80 \% \mathrm{CO}_{2}+20 \% \mathrm{~N}_{2}$ 
을 보였으나 60 과 $80 \% \mathrm{CO}_{2}$ 를 처리한 구에서는 0.26 과 $0.20 \mathrm{Log} \mathrm{CFU} / \mathrm{cm}^{2}$ 으로 유의적인 감소를 나타내었다 $(p<0.05)$. 저장 3 일에는 대조구가 1.26 을 나타낸 반면에 $\mathrm{CO}_{2}$ 의 비율이 $20,40,60,80 \%$ 증가함에 따라 $1.20,0.68$, $0.36,0.36 \mathrm{Log} \mathrm{CFU} / \mathrm{g}$ 로 $\mathrm{CO}_{2}$ 의 비율이 $40 \%$ 이상이 되면 Coliform 수도 유의적으로 감소하였다 $(p<0.05)$. 저장 6 일 에서는 $\mathrm{CO}_{2}$ 와 $\mathrm{N}_{2}$ 처리에 따른 유의적인 차이는 보이지 않 았다.

\section{포장용기의 형태 변화}

가스치환 비율에 따라 포장용기의 형태 변화를 가져왔 는데, 가스치환 포장 용기 내의 가스가 $20 \% \mathrm{CO}_{2}+80 \%$ $\mathrm{N}_{2}, 40 \% \mathrm{CO}_{2}+60 \% \mathrm{~N}_{2}$ 에서는 저장기간 동안 포장용기에 변화가 없었으나 $60 \% \mathrm{CO}_{2}+40 \% \mathrm{~N}_{2}$ 이상의 처리구에서는 Fig. 1과 같이 포장용기의 형태가 변형되어 더 이상 상품 의 가치를 상실하였다. 이는 $\mathrm{CO}_{2}$ 가 낮은 온도에서 용해도 가 높기 때문에 포장용기 내에 $\mathrm{CO}_{2}$ 를 첨가하면 포장 내 식육표면에 흡수되어 원래 $\mathrm{CO}_{2}$ 가 차지하던 기체의 부피 가 감소함에 따라 음압이 형성되어 포장용기가 찌그러지 는 변형을 일으키게 된다(Kim, 2009). 반면에 $\mathrm{N}_{2}$ 는 대기 성분 중 가장 많은 비율 $(78 \%)$ 을 차지하고 있고 불활성 기 체로서 산소를 대체하거나 희석시키기 위한 충진제로서 사용되거나 포장의 찌그러짐을 방지하여 포장의 형태를 유지하기 위해 사용된다. 따라서 본 연구결과 닭 가슴육 의 저장성을 증진시키면서도 포장용기의 변형이 생기지 않는 $\mathrm{CO}_{2}$ 농도 $40 \%$ 이하와 $\mathrm{N}_{2} 60 \%$ 의 비율이 적절할 것 으로 판단된다.

\section{요 약}

닭고기 가슴육에 대하여 가스를 넣지 않는 대조구와 $\mathrm{CO}_{2}$ 와 $\mathrm{N}_{2}$ 를 혼합 처리한 가스치환포장구로 나누어 냉장저장 $\left(4^{\circ} \mathrm{C}\right)$ 한 결과 저장 1 일에 $80 \% \mathrm{CO}_{2}$ 의 첨가구에서 $\mathrm{pH}$ 의 유 의적인 감소를 나타내었다 $(p<0.05)$. 가슴육의 명도 $\left(\mathrm{L}^{*}\right)$ 는 모든 저장 기간 동안 $\mathrm{CO}_{2}$ 의 농도가 $60 \%$ 이상일 때 대조 구에 비해 유의적으로 증가하였으며 적색도 $\left(\mathrm{a}^{*}\right)$ 와 황색도 $\left(\mathrm{b}^{*}\right)$ 는 가스처리에 따른 유의적인 차이는 보이지 않았다. 단백질변성도 $(\mathrm{VBN})$ 와 지방산패도(TBARS)는 대조구에 비 하여 $60 \%$ 이상의 $\mathrm{CO}_{2}$ 처리구에서 감소를 보였다 $(p<0.05)$. 닭가슴육의 총균수는 저장 1 일에는 가스 처리군간의 유의 적인 차이를 보이지 않았으나 저장 3 일과 6 일에는 $40 \%$ $\mathrm{CO}_{2}$ 처리군에서 유의적인 감소를 나타내었다 $(p<0.05)$. 그 러나 $\mathrm{CO}_{2}$ 를 $60-80 \%$ 으로 고농도 처리 포장 하여 냉장 저 장 시 포장 용기가 찌그러지는 현상이 발생하여 상품성의 저하를 초래하였다. 따라서 상기의 성적을 고려할 때 닭 가슴살을 $\mathrm{CO}_{2}, \mathrm{~N}_{2}$ 를 이용한 가스치환하여 포장 시에는 $\mathrm{CO}_{2}$ 는 $40 \%$ 이하로 $\mathrm{N}_{2}$ 는 $60 \%$ 로 유지하는 것이 적절한
것으로 판단된다.

\section{참고문헌}

1. AOAC (1990) Official Methods of Analysis, 15th ed, Association of Official Analytical Chemists, Washington, DC, USA.

2. AOAC (1995) Official Methods of Analysis, 16th ed, Association of Official Analytical Chemists, Washington, DC, USA.

3. APHA (1985) Standard methods for the examination of dairy products. 15th ed, Richardson G. H. (ed) Am. Pub. Health Assoc. Washington, DC, USA.

4. Arashisar, S., Hisar, O., Kaya, M., and Yanik, T. (2004) Effects of modified atmosphere and vacuum packaging on microbiological and chemical properties of rainbow trout (Oncorynchus mykiss) fillets. Int. J. Food Microbiol. 97, 209-214.

5. Bailey, J. S., Thomson, J. E., and Cox, N. A. (1987) Contamination of poultry during processing. In: The microbiology of Poultry Meat Products. Schweigert B. S. (ed) Academic Press, Inc., USA.

6. Banks, H., Nickelson, R., and Finne, G. (1980) Shelf-life studies on carbon dioxide packaged finfish from the Gulf of Mexico. J. Food Sci. 45, 157-162.

7. Bran, W. L., Kraft, A. A., and Walker, H. W. (1970) Effects of carbon dioxide and vacuum packaging on color and bacterial count of meat. J. Milk Food Tech. 33, 77-82.

8. Church, N. (1994) Developments in modified-atmosphere packing and related technologies. Trends Food Sci. Technol. 5, 345-352.

9. Chouliara, E., Karatapanis, A., Savvaidis, I. N., and Kontominas M. G. (2007) Combined effect of oregano essential oil and modified atmosphere packaging on shelf life extention of fresh chicken breast meat, store at $4^{\circ} \mathrm{C}$. Food Microbiol. 24, 607-617.

10. Daniels, J. A., Krishnamurthi, R., and Risvi, S. S. H. (1985) A review of effects of carbon dioxide, on microbial growth and quality. J. Food Prot. 48, 532-537.

11. Dawson, P. L., Hon, H., Vollet, L. M., Clardy, L. B., Martinez, R. M., and Acton, J. C. (1995) Film oxygen transmission rate effects on ground chicken meat quality. Poult. Sci. 74, 1381-1387.

12. Farber, J. M. (1991) Microbiological aspects of modifiedatmosphere packaging technology-A review. J. Food Prot. 94, 58-70.

13. Finne, G. (1982) Modified and controlled-atmosphere storage of muscle foods. Food Technol. 36, 128-133.

14. Gill, C. O., Harrison, J. C. L., and Penney, N. (1990) The storage life of chicken carcasses packaged under $\mathrm{CO}_{2}$. Int. J. Food Microbiol. 11, 151-158.

15. Gill, C. O. and Mollin, G. (1991) Modified atmosphere and vacuum packaging. In: Food Preservatives. Russel, N. J. and Gould, G. W. (eds) Kluwer Academic Pub., New York, pp. 172-199. 
16. Holland, G. C. (1980) Modified atmospheres for fresh meat distribution. Proc. Meat. Ind. Res. Conf., Chicago, IL, 21-39.

17. Hood, D. E. and Mead, G. C. (1993) Modified atmosphere storage of fresh meat and poultry. In: Principles and applications of modified atmosphere packaging of food. Parry, R. T. (ed) Blackie Academic and Professional. London, UK, pp. 269-298.

18. Hotchkiss, J. H. (1989) Advances in and aspects of modified atmosphere packaging in fresh red meats. Proceed. 42nd Annual Reciprocal Meat Conference of the American Meat Science Association, National Life Stock and Meat Board, Chicago, IL, pp. 31-33.

19. Jakobsen, M. and Bertelsen, G. (2002) The use of $\mathrm{CO}_{2}$ in packaging of fresh red meats and its effect on chemical quality changes in the meat; A review. J. Muscle Foods 13, 143168.

20. Kang, S. N., Jang, A., Lee, S. O., Min, J. S., and Lee, M. (2002) Effect of organic acid on value of VBN, TBARS, color and sensory property of pork meat. J. Anim. Sci. Technol. 44, 443-452.

21. Kim, J., Marshall, M. R., and Wei, C. I. (1995) Antibacterial activity of some essential oil components against five food borne pathogens. J. Agric. Food Chem. 43, 2839-2845.

22. Kim, J. (2009) What is the modified atmosphere packaging (MAP)? Meat J. 44-50.

23. Ogrydziak, D. M. and Brown, W. D. (1982) Temperature effects in modified-atmosphere storage of seafood. Food Technol. 35, 86-96.

24. Patsias, A., Badeka, A.V., Savvaidis, I. N., and Konotominas, M. G. (2008) Combined effect of freeze chilling and MAP on quality parameters of raw chicken fillets. Food Microbiol. 25, 575-581.

25. Sawaya, W. N., Elnawawy, A. S., Abu-Ruwaida, A. S.,
Khalafawi, S., and Dashti, B. (1995) Influence of modified atmosphere packaging on shelf-life of chicken carcasses under refrigerated storage conditions. J. Food Safety 15, 3551.

26. SAS (1999) SAS/STAT Software. Release 8.1, SAS Institute Inc., Cary, NC, USA.

27. Stammen, K., Gerdes, D., and Caporaso, F. (1990) Modified atmosphere packaging of seafood. Food Sci. Nut. 29, 301331.

28. Veranth, M. F., and Robe, K. (1979) $\mathrm{CO}_{2}$-enriched atmosphere keeps fish fresh more than twice as long. Food Proc. 40, 76-79.

29. Vihavainen, E., Lundstrom, H. S., Susiluoto T., Koort J., Paulin L., Auvinen P., and Bjorkroth K. J. (2007) Role of broiler carcasses and processing plant air in contamination of modified-atmosphere-packaged broiler products with psychrotrophic lactic acid bacteria. Appl. Environ. Microbiol. 73, 1136-1145.

30. Wilhelm, K. A. (1982) Extended fresh storage of fishery products with modified atmospheres: A survey. Marine Fish Rev. 44, 17-20.

31. Witte, V. C., Krause, G. F., and Baile, M. E. (1970) A new extraction method for determining 2-thiobarbituric acid values of pork and beef during storage. J. Food Sci. 35, 582585.

32. Zaika, L. L., Kissinger J. G., and Wasserman, A. E. (1983) Inhibition of lactic acid bacteria by herbs, J. Food Sci. 48, 1455-1459.

33. 高坂知久 (1975) 肉製品の 鮮度保持と 測定. 食品工業. 18, 105-108.

(Received 2010.4.26/Revised 1st 2010.12.2, 2nd 2011.1.23/

Accepted 2011.1.24) 